\title{
Influenza virus infections
}

\author{
N. R. GRIST \\ University Department of Infectious Diseases, Ruchill Hospital, Glasgow G20 9NB
}

\begin{abstract}
Summary
Ninety-six strains of influenza $A$ and 113 influenza $B$ were found in the two MRC/PHLS surveys. In the general practitioner survey the majority of strains were isolated from cases diagnosed as influenza but in hospital most came from cases diagnosed as having other respiratory infections. In the latter survey isolation rates were higher in upper respiratory tract infection than in lower ones but in the general practice survey this trend was reversed. Influenza-like symptoms tended to increase with age, while coryza and vomiting was commoner in the younger age groups. The frequency of influenza virus infections found in the survey is compared with those found in Glasgow over the last decade and their effect on the incidence of lower respiratory tract infection discussed.
\end{abstract}

SINCE their first isolation in 1933, influenza viruses have been well established as the causes of the easily recognized phenomenon of epidemic or pandemic influenza occurring at intervals of a few years. Their impact on the community is reflected by sharp increases in sick absences from work, and particularly in older persons, by increases in lower respiratory disease and in deaths from pneumonia, bronchitis, and even in total mortality in the sharper outbreaks. The role of influenza viruses in other illnesses is less well established, and infections are rarely detected between the characteristic outbreaks which in this country usually occur in winter.

\section{Results of MRC/PHLS surveys}

Influenza viruses were isolated from $3 \%$ of the 6384 patients: type A from $1.6 \%$ of general practice patients and $1.4 \%$ of children in hospital, type B from $2.4 \%$ in general practice and $0.7 \%$ in hospital.

Season. Only a few scattered isolations of type A virus were made in 1965 but most areas were affected in the sharp 1966 outbreak. Most areas were involved in the type B outbreaks of 1965 and 1966. Although the outbreaks extended over 4-5 months, in any one centre influenza was mainly restricted to 2-3 weeks per practice and 2-3 months per hospital (see Poole \& Tobin, Figs. 1 and 2, this symposium).

Age. Isolation rates by age are shown in Table 1 . For both types the rates were lowest in the first 6 months of life, rising for type A to a maximum in the oldest adult group: school-children showed the highest isolation rates for influenza $B$.

Diagnosis. Isolation rates by diagnosis are shown in Table 2 , and were maximal $(20-43 \%)$ in patients diagnosed clinically as 'influenza'. Influenza viruses were isolated from patients with all other diagnoses but in small proportions-from over $3 \%$ of patients with tracheitis or bronchiolitis and pneumonia in general practice and with tonsillitis in hospital (type A). Isolation rates for both types by diagnosis and age are shown in Figs. 3 and 4 of Poole \& Tobin (this symposium) confirming the high rates in 'influenza' at all ages (18-50\%) and the low rates in other conditions with the highest values

TABLE 1. Influenza virus isolation rates $(\%)$ by age

\begin{tabular}{|c|c|c|c|c|c|c|c|c|}
\hline & $\begin{array}{c}\text { No. } \\
\text { isolated }\end{array}$ & $\begin{array}{l}\text { Isolation } \\
\text { rate }\end{array}$ & $\begin{array}{c}\text { No. } \\
\text { isolated }\end{array}$ & $\begin{array}{l}\text { Isolation } \\
\text { rate }\end{array}$ & $\begin{array}{c}\text { No. } \\
\text { isolated }\end{array}$ & $\begin{array}{l}\text { Isolation } \\
\text { rate }\end{array}$ & $\begin{array}{c}\text { No. } \\
\text { isolated }\end{array}$ & $\begin{array}{l}\text { Isolation } \\
\text { rate }\end{array}$ \\
\hline Hospital & \multicolumn{2}{|c|}{ 0-5 months } & \multicolumn{2}{|c|}{ 6-11 months } & \multicolumn{2}{|c|}{$1-4$ years } & \multicolumn{2}{|c|}{$5-14$ years } \\
\hline $\begin{array}{l}\text { Influenza A } \\
\text { Influenza B } \\
\text { Total } \\
\text { Total specimens }\end{array}$ & $\begin{array}{r}6 \\
2 \\
8 \\
682\end{array}$ & $\begin{array}{l}0.9 \\
0.3 \\
1.2\end{array}$ & $\begin{array}{r}5 \\
2 \\
7 \\
374\end{array}$ & $\begin{array}{l}1.3 \\
0.5 \\
1.8\end{array}$ & $\begin{array}{r}20 \\
7 \\
27 \\
1075\end{array}$ & $\begin{array}{l}1 \cdot 9 \\
0 \cdot 7 \\
2 \cdot 6\end{array}$ & $\begin{array}{r}3 \\
5 \\
8 \\
287\end{array}$ & $\begin{array}{l}1 \cdot 0 \\
1 \cdot 7 \\
2 \cdot 7\end{array}$ \\
\hline General practice & \multicolumn{2}{|c|}{$0-4$ years } & \multicolumn{2}{|c|}{$5-14$ years } & \multicolumn{2}{|c|}{$15-44$ years } & \multicolumn{2}{|c|}{$45+$ years } \\
\hline $\begin{array}{l}\text { Influenza A } \\
\text { Influenza B } \\
\text { Total } \\
\text { Total specimens }\end{array}$ & $\begin{array}{r}12 \\
20 \\
32 \\
985\end{array}$ & $\begin{array}{l}1 \cdot 2 \\
2 \cdot 0 \\
3 \cdot 2\end{array}$ & $\begin{array}{r}12 \\
34 \\
46 \\
1060\end{array}$ & $\begin{array}{l}1 \cdot 1 \\
3 \cdot 2 \\
4 \cdot 3\end{array}$ & $\begin{array}{r}16 \\
32 \\
48 \\
1249\end{array}$ & $\begin{array}{l}1 \cdot 3 \\
2 \cdot 6 \\
3 \cdot 9\end{array}$ & $\begin{array}{r}22 \\
11 \\
33 \\
672\end{array}$ & $\begin{array}{l}3 \cdot 3 \\
1 \cdot 6 \\
4 \cdot 9\end{array}$ \\
\hline
\end{tabular}




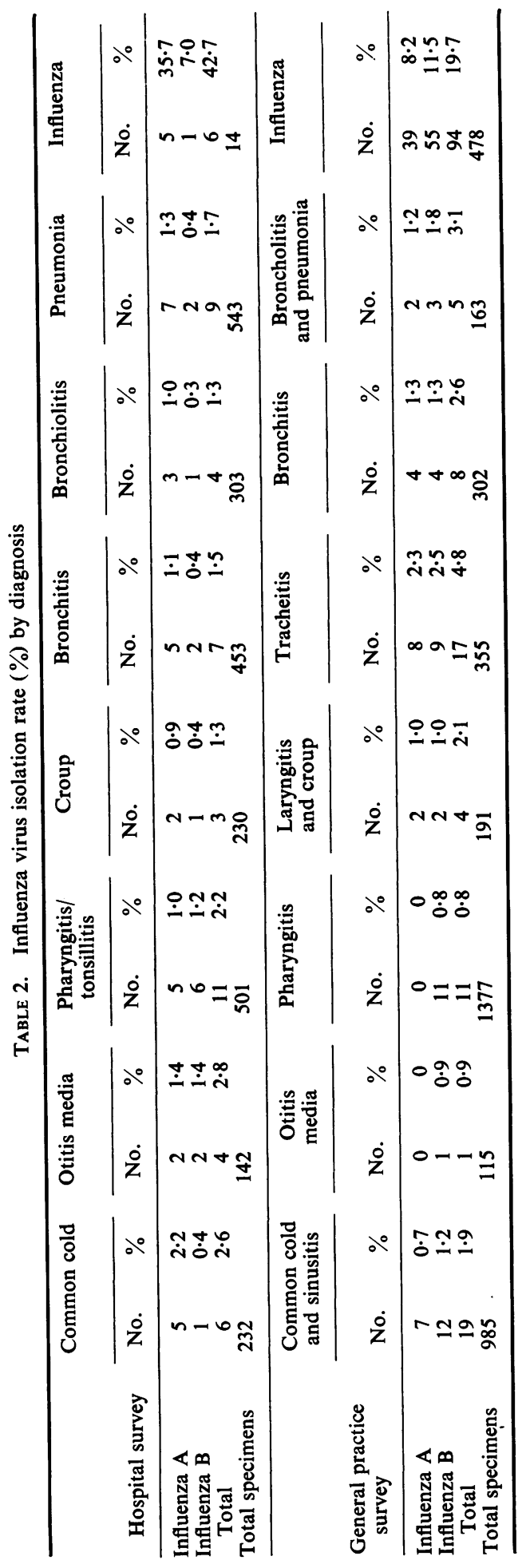


TABLE 3. Hospital: clinical features of influenza infections $(\%$ where $>30 \%)$

\begin{tabular}{|c|c|c|c|c|}
\hline & \multicolumn{3}{|c|}{ Influenza A } & \multirow{2}{*}{$\begin{array}{c}\text { Influenza } B \\
\text { Total } \\
0-15 \\
\text { years }\end{array}$} \\
\hline & $\begin{array}{c}<1 \\
\text { years }\end{array}$ & $\begin{array}{c}1-4 \\
\text { years }\end{array}$ & $\begin{array}{c}\text { Total } \\
0-15 \\
\text { years }\end{array}$ & \\
\hline No. of isolations & 15 & 23 & 42 & 22 \\
\hline Fever & 80 & 91 & 88 & 73 \\
\hline Cough & 93 & 74 & 83 & 73 \\
\hline Red pharynx & 33 & 61 & 52 & 68 \\
\hline Nose discharge & 73 & 61 & 64 & 36 \\
\hline Vomiting & 73 & 30 & 48 & 50 \\
\hline Tonsils red, no exudate & 20 & 39 & 33 & 59 \\
\hline Convulsions & 27 & 52 & 38 & 32 \\
\hline Red drums & 53 & 30 & 38 & 23 \\
\hline Dyspnoea & 47 & 22 & 29 & 36 \\
\hline $\mathrm{X}$-rays shadows & 27 & 22 & 24 & 32 \\
\hline Rhonchi & 40 & 4 & 17 & 36 \\
\hline Rales & 40 & 22 & 29 & 18 \\
\hline
\end{tabular}

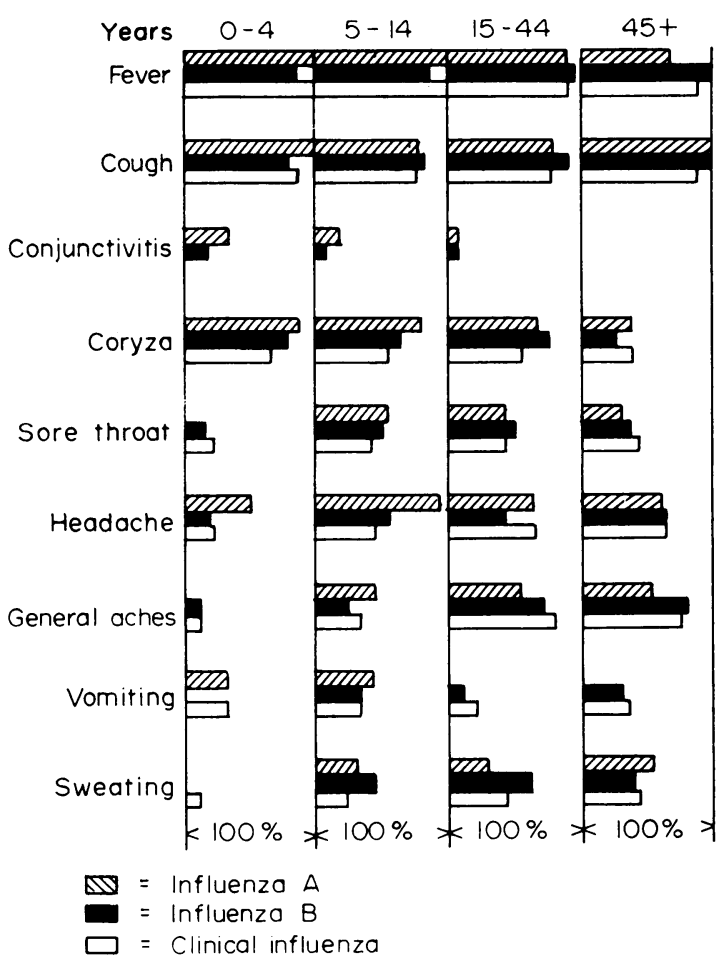

FIG. 1. Comparison of clinical features of virologically proven influenza and clinically categorized influenza cases. General practice survey.

(about $5 \%$ ) in tracheitis in children in general practice and in pharyngitis or tonsillitis in school-age children in hospital.
Clinical features. Tables 3 and 4 show the main clinical features associated with influenza virus infection. Fever and cough were reported in most patients of all age groups. Coryza and other upper respiratory features were common and present in most children, maximally in pre-school children in general practice. Clinical and radiological evidence of lower respiratory tract involvement were found in about a quarter of the children (half the infants) in hospital. In general practice, headache and general aches were more frequent in the adult groups and as shown in Fig. 1 the clinical features of virologically proven influenza corresponded closely to the symptom-complex diagnosed by practitioners as 'influenza' on clinical grounds alone.

\section{Discussion}

The results of the survey were disappointing in respect of influenza because, by chance, only small outbreaks of influenza occurred during the study period. This is illustrated by Fig. 2 which shows, for the City of Glasgow alone, the laboratory-diagnosed cases of influenza from 1964 to 1972 together with pneumonia notifications for children ( $<5$ years old) and 'adults' ( $>15$ years old). As is well known, the winter peaks of pneumonia in adults correspond to influenza outbreaks and are hardly detectable in influenza-free winters. The winter peaks of pneumonia in young children are out of phase and correspond not to influenza but to outbreaks of respiratory syncytial virus infection which is so much more important a cause of lower respiratory disease in this age group (Grist, Ross \& Stott, 1967). The outstanding importance of influenza as a cause of severe 
TABLE 4. General practice: clinical features of influenza infection ( $\%$ where $>30 \%)$

\begin{tabular}{|c|c|c|c|c|c|c|c|c|}
\hline & \multicolumn{4}{|c|}{ Influenza A } & \multicolumn{4}{|c|}{ Influenza B } \\
\hline & $\begin{array}{c}0-4 \\
\text { years }\end{array}$ & $\begin{array}{l}5-14 \\
\text { years }\end{array}$ & $\begin{array}{r}15-44 \\
\text { years }\end{array}$ & $\begin{array}{l}45+ \\
\text { years }\end{array}$ & $\begin{array}{c}0-4 \\
\text { years }\end{array}$ & $\begin{array}{l}5-14 \\
\text { years }\end{array}$ & $\begin{array}{r}15-44 \\
\text { years }\end{array}$ & $\begin{array}{l}45+ \\
\text { years }\end{array}$ \\
\hline No. of isolations & 13 & 14 & 18 & 22 & 20 & 36 & 37 & 12 \\
\hline $\begin{array}{l}\text { Fever } \\
\text { Cough } \\
\text { Coryza } \\
\text { Headache } \\
\text { General aches } \\
\text { Sweating } \\
\text { Sore throat } \\
\text { Vomiting } \\
\text { Conjunctivitis } \\
\text { Drowsiness }\end{array}$ & $\begin{array}{r}100 \\
100 \\
92 \\
38 \\
- \\
- \\
31 \\
31 \\
31\end{array}$ & $\begin{array}{r}100 \\
79 \\
79 \\
86 \\
43 \\
57 \\
36 \\
-\end{array}$ & $\begin{array}{l}94 \\
83 \\
72 \\
61 \\
50 \\
39 \\
- \\
-\end{array}$ & $\begin{array}{r}73 \\
100 \\
50 \\
59 \\
59 \\
50 \\
32 \\
- \\
-\end{array}$ & $\begin{array}{l}85 \\
80 \\
80 \\
- \\
- \\
- \\
- \\
-\end{array}$ & $\begin{array}{l}86 \\
83 \\
64 \\
58 \\
31 \\
56 \\
- \\
-\end{array}$ & $\begin{array}{l}95 \\
92 \\
76 \\
49 \\
62 \\
43 \\
57 \\
- \\
-\end{array}$ & $\begin{array}{r}100 \\
100 \\
33 \\
67 \\
83 \\
33 \\
33 \\
- \\
-\end{array}$ \\
\hline
\end{tabular}

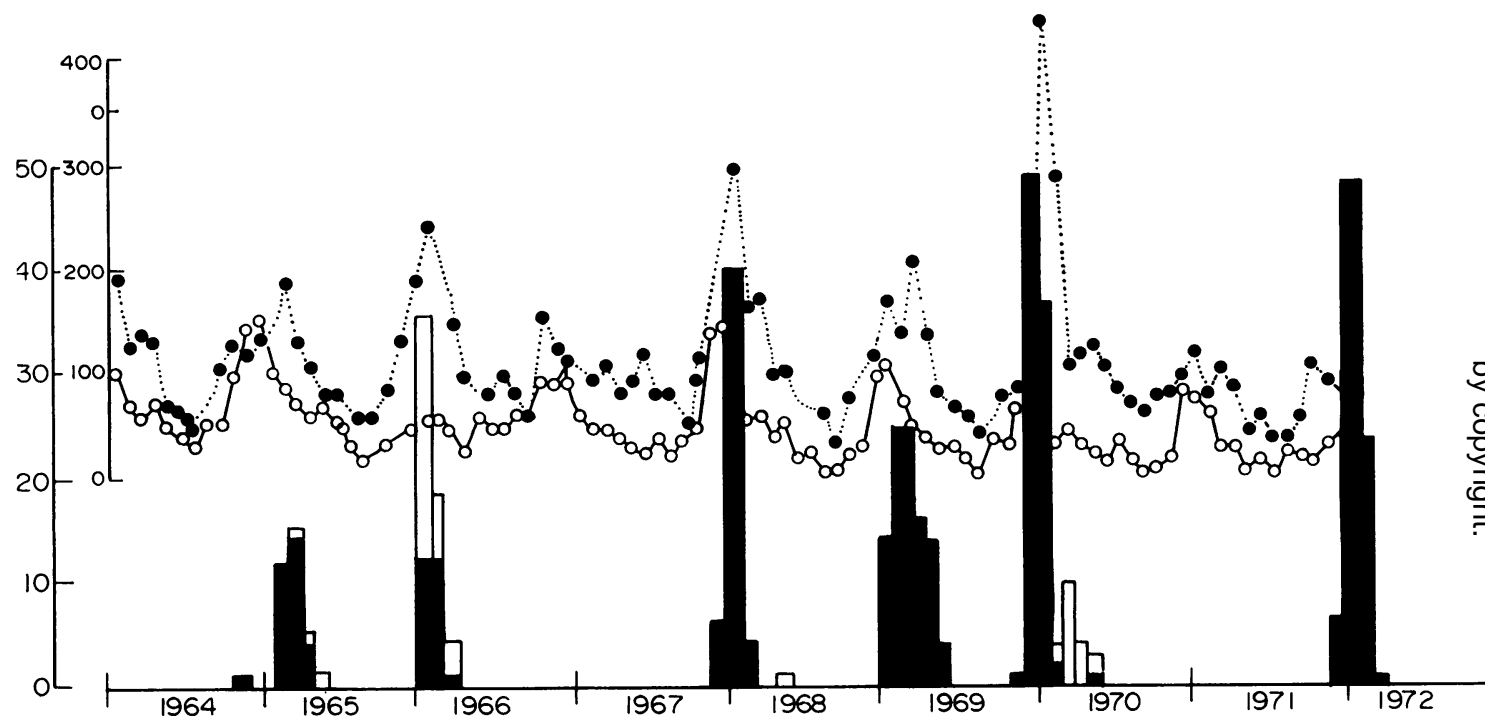

FIG. 2. Influenza diagnosis by Regional Virus Laboratory and pneumonia notifications. Key: solid columns, influenza $A$; open columns, influenza B; dotted line, pneumonia $>15$ years old; continuous line, pneumonia $<5$ years old; left-hand scale, cases of influenza; right-hand scale, pneumonia notifications.

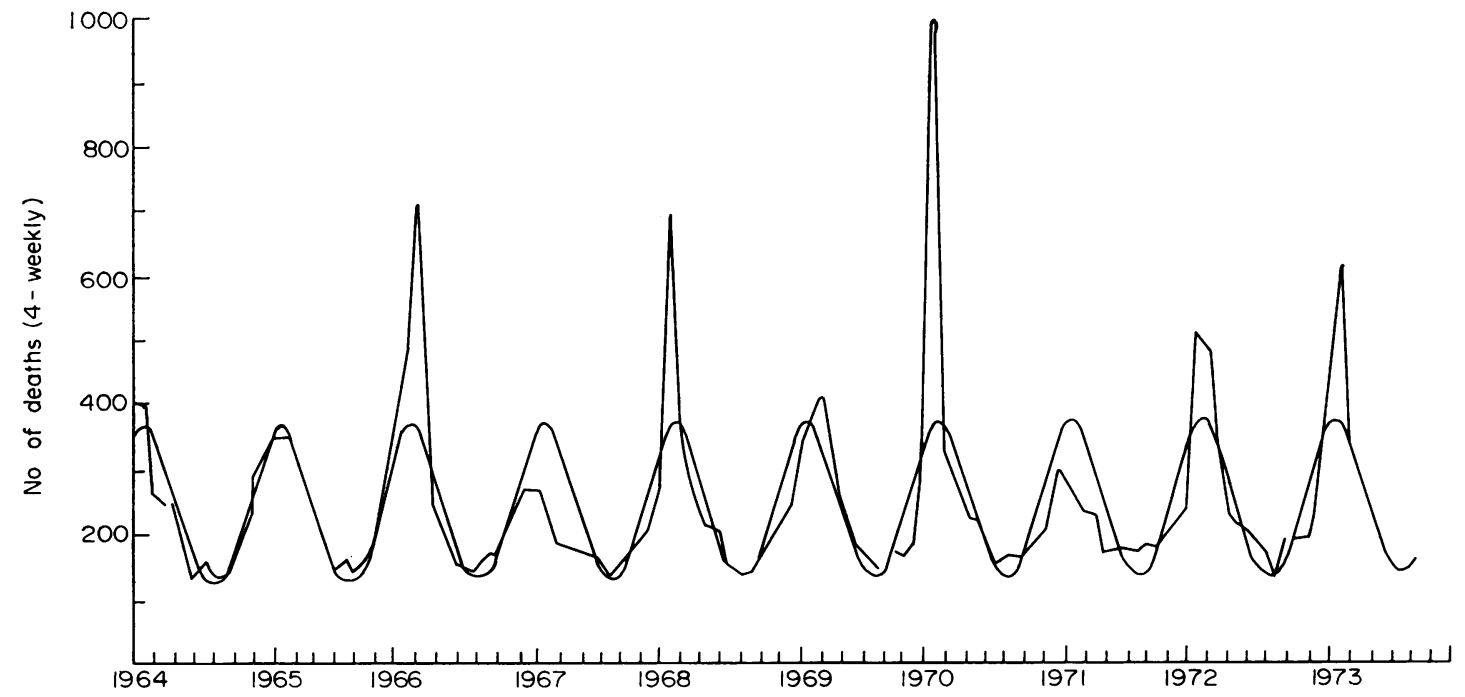

FIG. 3. Mortality curve for Scotland in relation to 'expected seasonal mortality' for influenza, pneumonia and bronchitis, 1964-73. 
lower respiratory diseases is such that its contribution to 'excess mortality' based on death notifications for influenza, pneumonia and bronchitis may be used as an index for international comparisons. This is illustrated by Fig. 3 in which the curve of expected mortality was calculated on the computer programme of the Virus Unit of the World Health Organization (I am indebted to Dr D. Reid of the
Communicable Diseases (Scotland) Unit for permission to publish this diagram from Communicable Diseases (Scotland) weekly report 73/11).

\section{Reference}

Grist, N.R., Ross, C.A.C. \& Stotr, E.J. (1967) Influenza, respiratory syncytial virus, and pneumonia in Glasgow, 1962-5. British Medical Journal, 1, 456. 